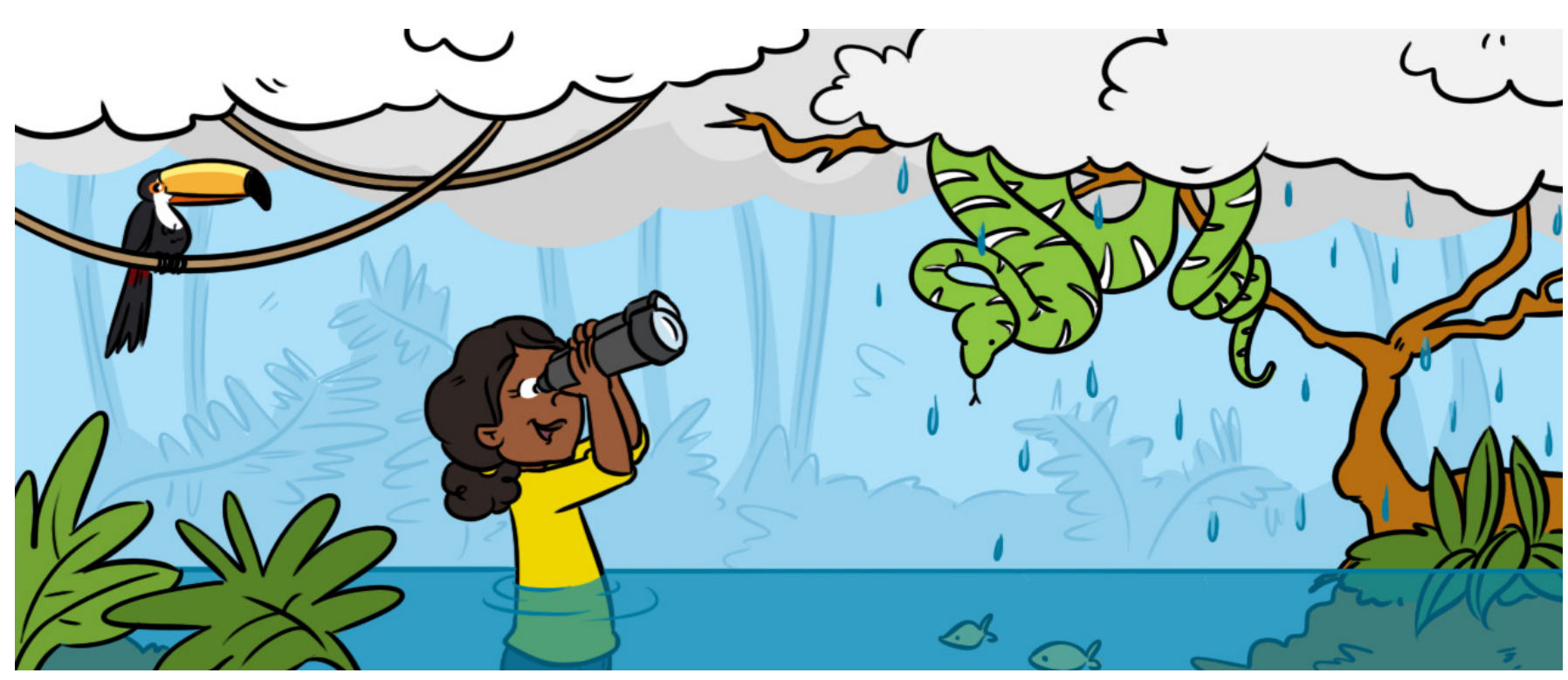

\title{
WATER CONTROLS AMAZONIAN BIODIVERSITY
}

\section{Amanda Frederico Mortati ${ }^{* *}$ and Thiago André ${ }^{2}$}

1'Instituto de Biodiversidade e Florestas, Universidade Federal do Oeste do Pará, Santarém, Brazil, 2Instituto de Ciências e Tecnologia das Águas, Universidade Federal do Oeste do Pará, Santarém, Brazil

\section{REVIEWED BY:

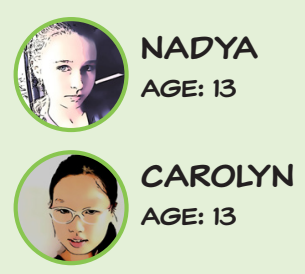

Almost everything about the Amazon River is truly gigantic and amazing. It crosses more than $7,000 \mathrm{~km}$. The area from which water and materials drain into the Amazon River from higher lands to the river's lowland plains covers about 7 million $\mathrm{km} 2$. This area connects aquatic and terrestrial ecosystems that contain $20 \%$ of the Earth's fresh water and most of the Earth's diversity of living organisms. Humid areas, where bodies of water directly affect biodiversity, cover $30 \%$ of Amazonia. Water in various forms, from flying rivers in the form of clouds, to rainfall, to flow of water from highlands to lowlands, is a major factor affecting biodiversity Amazonia. You can see this effect all over Amazonia, and water has controlled the ecosystem of this area for many years. The Amazon contains numerous species that together form a complex forest, both on land and underwater.

\section{THE BIGGEST RIVER ON EARTH}

Amazonia is the area drained by the Amazon River, and Amazonia covers about 7 million $\mathrm{km}^{2}$. This massive area contains a large proportion of the world's microbial, animal, and plant species that together form a complex forest, both above ground and underwater. Almost everything about this mighty river is truly gigantic and amazing. The Amazon crosses more than 7,000 km 


\section{FIGURE 1}

Northern South America, as mapped by Shuttle

Radar Topographic Mission (http://dds.cr. usgs.gov/srtm/).

The area from which the larger image is taken is indicated by the box over the picture of the earth in the upper right corner.

The larger image shows differences in altitude above sea level represented by colors: green indicate lower lands, where big rivers are; yellow indicate the old exposed rocks and soils; and white indicate mountain ranges, the Andes.

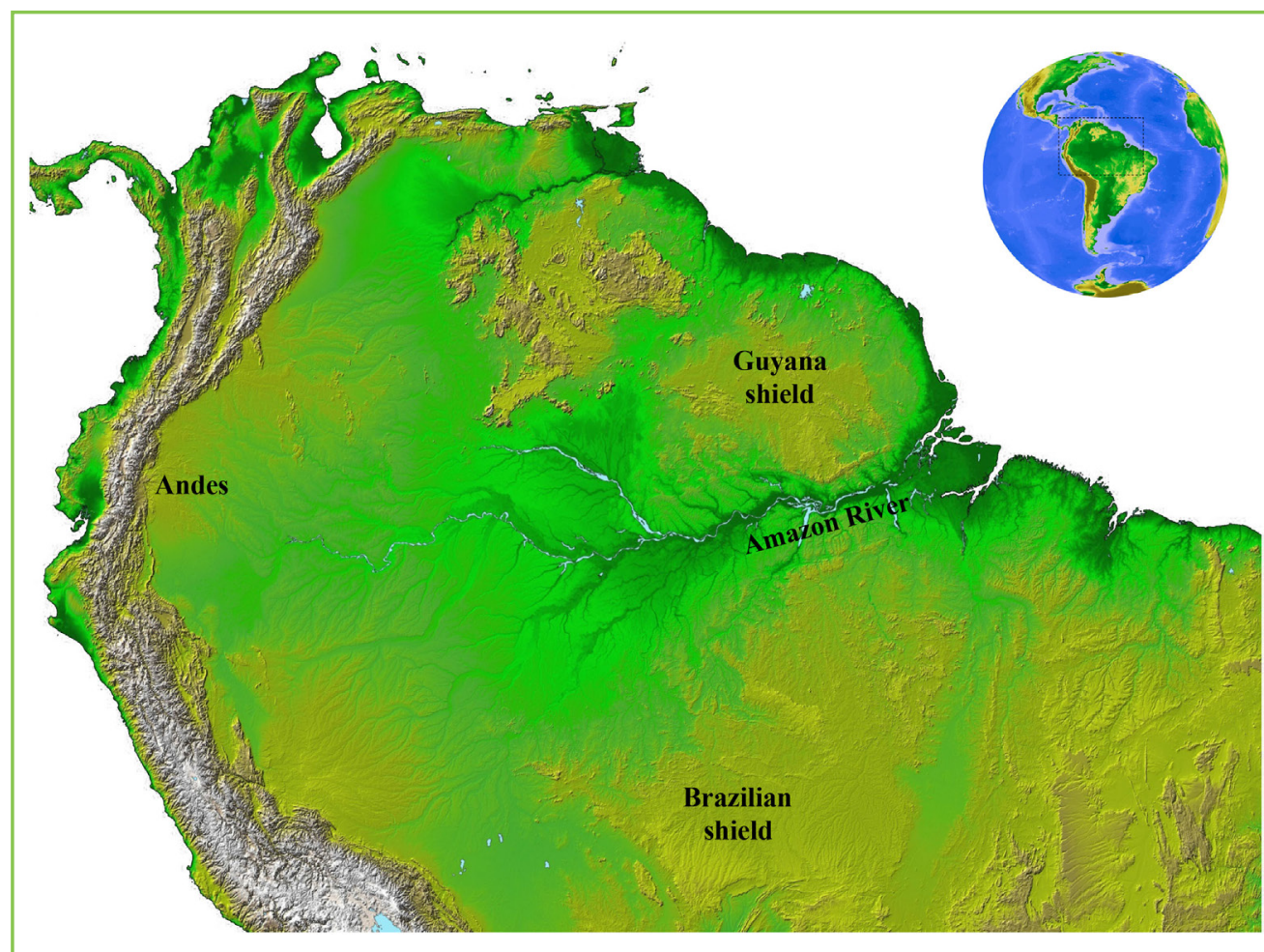

FIGURE

of northern South America, from the Apurímac River at the Andes Mountains of south Peru to the Atlantic Ocean in north Brazil (Figure 1).

Water is the main constituent of cells. It is essential for life because biological functions, such as respiration, photosynthesis, and digestion, happen in water. Rivers, streams, underground water, and clouds connect and sustain every living organism in the Amazonian forest. Therefore, water is the source of Amazonia's biodiversity.

The Amazon River is about 9 million years old. During the rainy season, the Amazon River can be up to $50 \mathrm{~km}$ wide at certain places. A water basin, or watershed, is the area where water and materials, such as sand, living organisms, trunks, and fragmented leaves, are drained through streams and rivers, moving from the watershed's higher lands to its lowland plains, because of gravity. This downhill flow of water connects aquatic and ter restrial ecosystems in the Amazon River's watershed, which covers a bigger area than the whole of Europe and contains $20 \%$ of all the freshwater in the world. Amazonia also houses most of the Earth's diversity of living organisms [1].

In Amazonia, we can find between 4,000 and 15,000 plant species (including Brazil nut and açaí), >400 mammal species (including jaguars, sloths, and bats), >1,300 bird species (including toucan and harpy eagle), $>400$ reptile species (including boa snakes and caimans), $>400$ amphibian species (including tree frogs), and around 3,000 freshwater fish species (including 
piranhas and pirarucu). The diversity of smaller life forms is harder to estimate, and scientists have described more than 100,000 invertebrate species, like insects and spiders. The number of fungi and algae species are also difficult to estimate and many new species are being described every month. All this biodiversity is dependent on the unique water dynamic found in the region.

\section{RIVERS THAT CAN FLY}

Amazonia is a tropical landscape covered mainly by rainforests. The rain that falls on Amazonian rivers and forests comes from evaporation of the Atlantic Ocean and from the metabolism of the Amazonian ecosystem itself. Rainwater can reach rivers directly or can be captured by the forest, run throughout the canopy and trees trunks and finally reach the ground. Groundwater can then flow downhill to smaller rivers, carrying soil and other materials with it, and incorporate the runoff or infiltrate into soil into reservoirs. These processes are part of what we call the hydrological (water) cycle of a watershed. The hydrological cycle starts with precipitation (rainfall), which is followed by the runoff of that water into streams and rivers, infiltration of water into the

EVAPOTRANSPIRATION

a phase of the hydrological (water) cycle that includes evaporation of water from soil and water surfaces, as well as from the stems, leaves, and flowers of plants. ground, and a process called evapotranspiration, in which water is returned to the atmosphere through evaporation from soil and water surfaces or from the leaves, stems, or flowers of plants.

Vegetation along the edges of streams and rivers helps to decrease and slow down water runoff into those bodies of water. These zones are called riparian zones and the plants there are called riparian vegetation. Riparian vegetation has two main roles: first, it feeds water back into the atmosphere, through evapotranspiration; and second, it softens the fall of water hitting the ground helping the infiltration processes, which gives back water to the soil. Big trees with large root systems can then access the underground water even during drier seasons. Some trees can release up to 1,000 l of water into the atmosphere each day!

As a result, Amazonia and its big rivers act like water vapor bombs, which put water into the atmosphere and form a dense layer of clouds that contain large amounts of water. These clouds flow with the winds, forming incredible flying rivers. Because of the high temperatures in Amazonia and the large amount of rain that falls around the equator, Amazonia has this massive power to exchange water between the forest and the atmosphere. The 4,000-m high Andean cordillera at the west of the South American continent acts as a barrier to winds and clouds coming across the continent and from the Atlantic Ocean. The result is a massive amount of rainfall on the areas of central, eastern, and southern Brazil and its neighboring countries. This river of clouds transports billions of liters of water in vapor form each year, which is almost 
equal to the amount of water flowing from the Amazon River itself into the ocean each year. So, these rivers in the sky change the climate of the continent and, eventually, that of the whole world.

\section{RIVERS THAT PULSE}

The thick cloud layer pours its heavy rainfall down onto lowlands, forcing the big rivers to flood and water from the rivers to spread to higher lands, submerging many plants living in those higher areas [2]. These forests flood each year, so these forests have a terrestrial phase and an aquatic phase every year (Figure 2). The floodwaters in these forests can reach up to $8 \mathrm{~m}$ high for as long as 300 days! Most trees in these forests spend half of the year outside of water and the other half in different levels of submergence. These flooding forests contain more than 1,000 tree species. This pulsing water system controls many of the plants' biological processes, like flowering growth, which in turn influence terrestrial animal communities, which feed on or live in these forests. Aquatic animals, like fish and freshwater dolphins, also feed on and live in these flooded forests when the water level is high.

Species change from highland streams down to bigger rivers and their flooded forests, lower along the watershed [3]. Such succession in environmental structure determined by water is seen both in species composition as in forest structure, likely a result of adaptation to different levels

\section{FIGURE 2}

Flood pulse of Amazonian rivers, showing the terrestrial and aquatic phases of riparian vegetation.

The upper inset image shows rainfall over a stream that flows into the Tapajós River, with a wide flooded forest on its edges; the lower inset image shows a typical terra firme stream and its riparian vegetation.

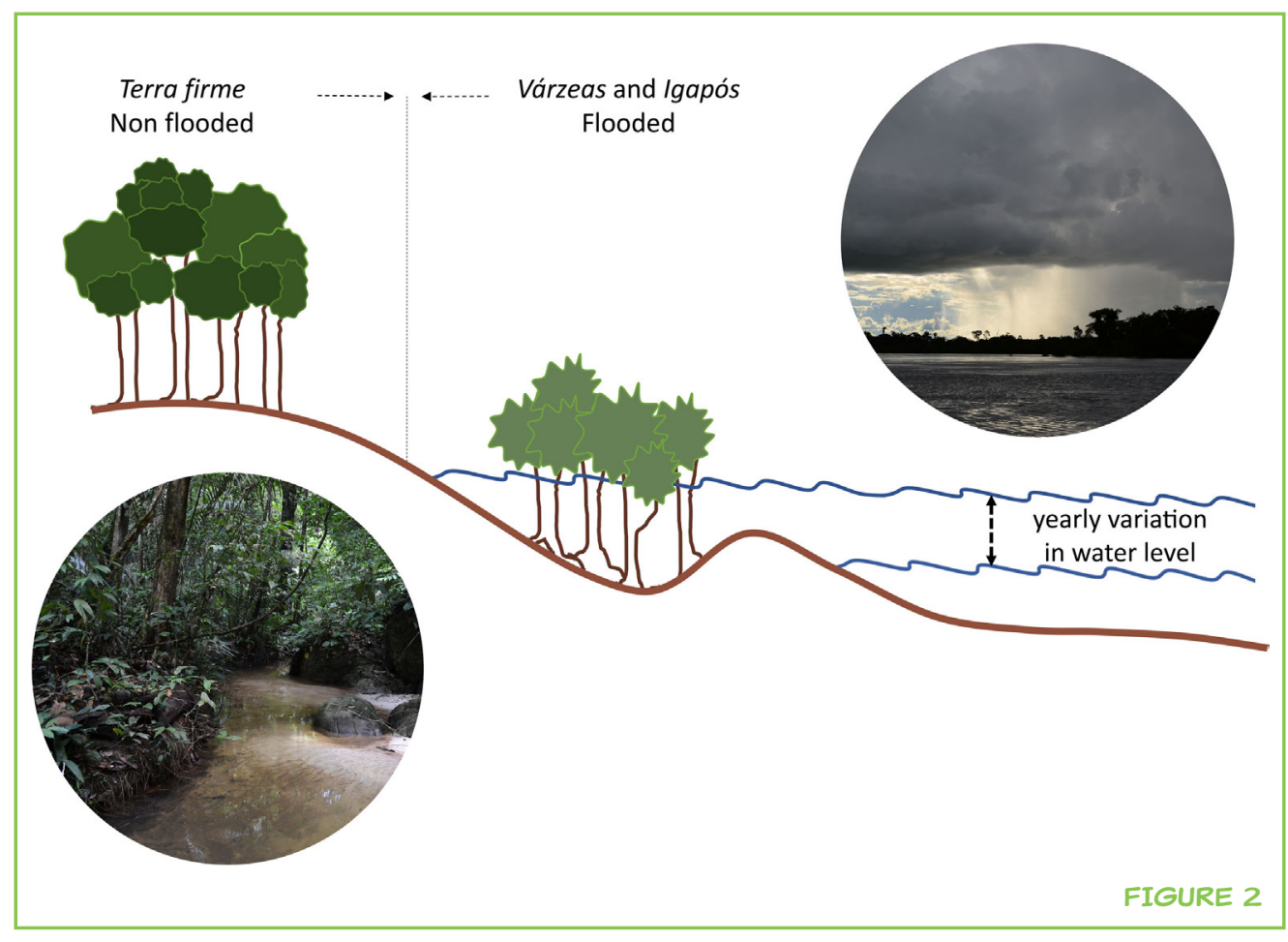




\section{VARZEA}

areas flooded by rivers that are rich in suspended material eroded from the Andes Mountains, which makes the water whitish (for example, Solimões River and Madeira River).

\section{IGAPÓ}

areas flooded by rivers with acidic water, formed in the highlands of the Guyana and Brazilian old exposed rocks (for example, Negro River and Tapajós River).

\section{TERRA FIRME}

area above the floodplains of major rivers, where local vegetation is not seasonally flooded. of water in the soil [4]. In other words, each stream seems to be unique in the matter of which species arises in such environments.

Incredibly, flooded forests can be very different from each other. Depending on what the river floor is made of, the types of species present in the flooded forests can vary. The rivers in Amazonia have two main origins: the young soils of the Andes Mountains and the ancient soils of the Brazil and Guyana old exposed rocks. Rivers that flow over young soils create flooded forests called Várzea forests, and rivers that flow over ancient soils create flooded forests called Igapó forests. These two kinds of forests are very different in tree species and overall size. The geological origin of the river affects the water's chemical properties, which results in remarkable differences in water color: Várzea forests occur along white water rivers, and Igapó forests on black or clear water rivers.

\section{RIVERS THAT FLOW UNDERGROUND}

Plants and animals that live in riparian habitats on the edges of rivers and streams respond to the amount of water present in the soil. The pulse of water in riparian habitats is much more random and less predictable than it is in rivers since most of variation in water level in riparian habitats comes from rainfall directly over these habitats. Terrestrial and aquatic compartments in terra firme Amazonia are intimately related and changes in one can have huge consequences in the other. For instance, it has been shown that degradation of riparian forests can lead to reduction in aquatic species number [5].

On higher lands in Amazonia that are not directly affected by the flooding of big rivers, water also rules biodiversity. These humid areas, covering about 1 million $\mathrm{km}^{2}$, contain a dense and connected network of small streams, which are formed and maintained by underground water. These small streams are actually where most of the water in the big rivers originally comes from.

\section{WATER CONTROLS AMAZONIAN BIODIVERSITY}

From flying rivers in the form of clouds, through rainfall and the flow of water from highlands to lowlands, water is a major factor affecting biodiversity in Amazonia. Amazonian species have evolved many ways of living in or interacting with water, leading to high number of species in each area. Also, most Amazonian human populations live near its rivers and are also accustomed to the pulsing rhythms of those rivers. Amazonian forests are essential for Amazonia's contribution to the environment. Locally, these forests affect water quality and distribution, and more globally, they can affect the stability of 
the climate. Water has controlled the ecosystem of this area for many years. So, you can clearly see that water in many ways creates different habitats that result in this biodiversity.

\section{REFERENCES}

1. Lewinsohn, T. M., and Prado, P. I. 2005. How many species are there in Brazil? Conserv. Biol. 19(3):619. doi:10.1111/j.1523-1739.2005.00680.x

2. Junk, W. F., Piedade, M. T. F., Schöngart, J., Cohn-Haft, M., Adeney, J. M., and Wittmann, F. 2011. A classification of major naturally-occurring Amazonian lowland wetlands. Wetlands 31(4):623-40. doi:10.1007/s13157-011-0190-7

3. Schietti, J., Emilio, T., Rennó, C. D., Drucker, D. P., Costa, F. R. C., Nogueira, A., et al. 2014. Vertical distance from drainage drives floristic composition changes in an Amazonian rainforest. Plant Ecol. Divers. 7(1-2):241-53. doi:10.1080/17550874. 2013.783642

4. Wittmann, F., Schöngart, J., Junk, W. J., and Parolin, P. 2010. Phytogeogarphy, species diversity, community structure and dynamics of Amazonian floodplain forests. In Amazonian Floodplain Forests: Ecophysiology, Biodiversity and Sustainable Management (Ecological Studies), org. ed. W. J. Junk, M. T. F. Piedade, F. Wittmann, and J. Schöngart. Netherlands: Springer. p. 61-102.

5. Dias, M. S., Magnusson, W. E., and Zuanon, J. 2010. Effects of reduced-impact logging on fish assemblages in Central Amazonia. Conserv. Biol. 24(1):278-86. doi:10.1111/j.1523-1739.2009.01299.x

SUBMITTED: 30 January 2018; ACCEPTED: 22 August 2018;

PUBLISHED ONLINE: 10 September 2018.

EDITED BY: Ana Maria Rocha De Almeida, California State University, East Bay, United States

CITATION: Mortati AF and André T (2018) Water Controls Amazonian Biodiversity. Front. Young Minds 6:47. doi:10.3389/frym.2018.00047

CONFLICT OF INTEREST STATEMENT: The authors declare that the research was conducted in the absence of any commercial or financial relationships that could be construed as a potential conflict of interest.

COPYRIGHT @ 2018 Mortati and André. This is an open-access article distributed under the terms of the Creative Commons Attribution License (CC BY). The use, distribution or reproduction in other forums is permitted, provided the original author(s) and the copyright owner(s) are credited and that the original publication in this journal is cited, in accordance with accepted academic practice. No use, distribution or reproduction is permitted which does not comply with these terms. 


\section{REVIEWED BY}

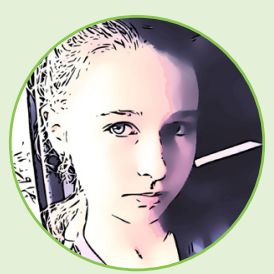

\section{NADYA, AGE: 13}

I love to paint and read and I want to become an art teacher when I grow up. My favorite books are the Harry Potter series. I am usually in my room painting or making jewelry. Art and science are my favorite subjects in school. It is interesting to learn about this planet and I want to make a difference in it someday.

\section{CAROLYN , AGE: 13}

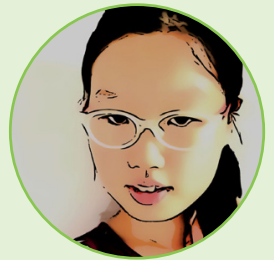

As a child, I always dreamed of becoming a scientist. I was interested in all sorts of science. When I was seven years old, I became intrigued by zoology and enjoyed TV shows about wild animals and environment. My interest in animals grew after I encountered one bear, four deers, and an uncountable amount of seals last year. Although I do want to become an artist, becoming a scientist is still high in my priority.
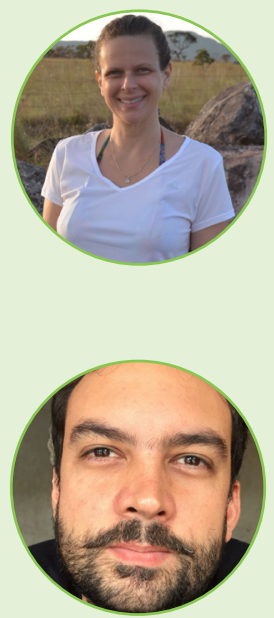

\section{AUTHORS}

\section{AMANDA FREDERICO MORTATI}

I am an ecologist interested in streams. I have been studying aquatic processes in the Amazon for 15 years and discovered that variation in stream structure here is high enough to make each stream a unique place for biodiversity. I teach watershed ecology and management at the Federal University of West Pará, in Brazil. I also love to walk on the beach during sunsets. *amortati@gmail.com

\section{THIAGO ANDRÉ}

I am an evolutionary biologist interested in plant diversity. My research focuses on diversification of ginger plants, especially Amazonian Costaceae, Zingiberaceae, and Marantaceae. I teach plant evolution at the Federal University of West Pará, in Brazil. You can find me reading under a tree or nurturing my garden during weekends. 